\title{
Long-term follow-up of seven patients with ophthalmopathy not associated with thyroid autoimmunity: heterogeneity of autoimmune ophthalmopathy
}

\author{
This article was published in the following Dove Press journal: \\ Clinical Ophthalmology \\ II July 2012 \\ Number of times this article has been viewed
}

\author{
Tom McCorquodale' \\ Hooshang Lahooti' \\ Bamini Gopinath ${ }^{2}$ \\ Jack R Wall' \\ 'Department of Medicine, Nepean \\ Clinical School, the University of \\ Sydney, Penrith, NSW, Australia; \\ ${ }^{2}$ Centre for Vision Research, the \\ University of Sydney, Westmead \\ Hospital, Westmead, NSW, Australia
}

Correspondence: Jack R Wall University of Sydney, Nepean Hospital, PO Box 63, Penrith NSW 275I, Australia Tel +6I 0247342613

Fax +6I $02473426 I 4$

Email jackw@med.usyd.edu.au
Background: Ophthalmopathy is the most common extrathyroidal manifestation of Graves' disease. However, in approximately $5 \%$ of cases this autoimmune eye disorder occurs in the apparent absence of Graves' hyperthyroidism: the so-called euthyroid Graves' disease (EGD).

Methods: Seven patients with EGD were followed for evidence of thyroid and orbital autoimmunity, for up to 10 years. Calsequestrin and collagen XIII antibodies were measured by enzyme linked immunosorbent assay (ELISA), and TSH-receptor (TSH-r) antibodies were measured as TSH-r-binding antibody (TRAb) and thyroid-stimulating immunoglobulin (TSI). Eye signs were characterized and quantified as clinical activity score (CAS), NOSPECS classes, Nunery types 1 and 2, and margin-reflex distance (MRD).

Results: Calsequestrin antibodies were detected on at least one occasion in three of the seven patients and collagen XIII antibodies were detected one or more times in five patients. In one patient with isolated congestive ophthalmopathy who was studied intensely, collagen XIII antibodies were initially positive and then became negative as the eye disease stabilized, while antibodies targeting calsequestrin were always negative. TRAb was not detected in any patient, but TSI was detected in three patients on one occasion each. Ultrasound abnormalities were found in four of the six patients for whom this was carried out, but there was no clear evidence for thyroiditis in any of these patients. For comparison, 13 patients were studied with typical Graves' ophthalmopathy. There were no significant differences compared to EGD in respect to the prevalence of positive calsequestrin or collagen XIII antibodies, but these patients included more smokers (eight out of 13 versus none out of seven).

Conclusions: Earlier studies suggesting that patients with EGD eventually develop thyroid dysfunction have not been confirmed here, although follow-up continues, and the possibility that such patients have had thyroid autoimmunity in the past, or that they will develop it in the future cannot be excluded. Overall, it is likely that the ophthalmopathy associated with Graves' hyperthyroidism is the same disease as that observed in patients - such as those reported here - in whom thyroid dysfunction and thyroid autoimmunity are not present during the period of follow-up. The role of autoimmunity against the TSH-r in euthyroid patients with ophthalmopathy has not been proven and the significance of the orbital antibodies is unclear.

Keywords: ophthalmopathy, thyroid eye disease, collagen XIII, calsequestrin, euthyroid Graves' disease

Ophthalmopathy is the most common extrathyroidal manifestation of Graves' disease occurring in approximately $50 \%$ of patients. ${ }^{1-3}$ General, mild ophthalmopathy also occurs in a small proportion of patients with transient (subacute, silent) 
thyroiditis ${ }^{4}$ and in about one-third of patients with progressive (Hashimoto's) thyroiditis. ${ }^{5}$ In approximately 5\% of cases, ophthalmopathy occurs in the absence of Graves' hyperthyroidism, where it is called EGD, even though this is an incorrect description of the disorder since these patients do not have, or do not develop over a 10-year period (as will be shown here), Graves' hyperthyroidism. However, for the purpose of this study we will refer to these patients as having "EGD."

The association between thyroid autoimmunity and ophthalmopathy is best explained by cross-reactivity against a thyroid- and orbital-tissue-shared antigen such as the TSH-r, which is expressed in the orbital preadipocyte ${ }^{6,7}$ and TSH-r antibodies are generally accepted as playing a role in the pathogenesis of thyroid-associated ophthalmopathy. ${ }^{8,9}$ However, their role in EGD is unclear; consequently, other possibilities must be considered. ${ }^{10}$

Several other autoantibodies are associated with ophthalmopathy; in particular, those targeting the calciumbinding skeletal muscle protein calsequestrin $\left(\mathrm{CASQ}_{1}\right)$, which is localized to the sarcoplasmic reticulum of the skeletal muscle fibre $^{11}$ and to the fibroblast cell membrane protein collagen XIII. ${ }^{12}$ Antibodies against $\mathrm{CASQ}_{1}$ are sensitive indicators of the ocular myopathic subtype of ophthalmopathy in patients with Graves disease, ${ }^{13,14}$ while those targeting collagen XIII are linked to the congestive ophthalmopathy subtype. ${ }^{15}$ Here, seven patients with EGD have been studied, including one patient with severe isolated congestive ophthalmopathy who was studied intensively over a 6-year period - in whom collagen XIII antibodies were positive in the early stages, while calsequestrin antibodies were always negative and, for comparison, 13 patients with typical Graves' ophthalmopathy were examined. The findings suggest that the ophthalmopathy of EGD and that associated with thyroid autoimmunity are the same disease, and in both cases are associated with other autoimmune disorders or markers.

\section{Patients and methods Clinical subjects}

Seven patients with EGD, six females and one male, aged 30-63 years (mean age 51 years) were studied. Their demographic data, baseline thyroid function, and thyroid ultrasound findings are summarized in Table 1. Thyroid antibody testing results and details of any other personal or family history of autoimmunity are shown in Table 2 . Three of the patients (patients 2, 4, and 5, Table 3), who had severe active disease, were being treated with steroids at the time of their first visit to the Thyroid Clinic and they all subsequently improved. The other four had never been treated with steroids or immunosuppressive drugs. For comparison, we studied 13 patients with typical "Graves' ophthalmopathy" (ie, ophthalmopathy associated with Graves' hyperthyroidism) matched for age, sex, ethnicity, and severity and activity of the eye disease with the seven patients with EGD. Their demographics and other details are shown in Table 5.

\section{Eye assessment}

The grade, severity, and activity of the ophthalmopathy were classified as: (1) Nunery type 1 (without restrictive myopathy) or type 2 (with restrictive myopathy); ${ }^{16}(2)$ CAS (0-10) of Mourits et $\mathrm{al},{ }^{17}$ which is a measure of disease activity; (3) Werner's NOSPECS classes; ${ }^{18}$ and (4) upper eyelid MRD, which is the distance between the center of the pupillary light reflex and the upper eyelid margin with the eye in primary gaze, as a measure of eyelid retraction; an MRD of $>5 \mathrm{~mm}$ is taken as a significant upper eyelid retraction (UER). The degree of proptosis (mm) was measured using a Hertel exophthalmometer, where a positive reading was defined as $\geq 18 \mathrm{~mm}$ in either eye or $>2 \mathrm{~mm}$ difference between the eyes.

\section{Methods}

Serum $\mathrm{CASQ}_{1}$ and collagen XIII antibodies were measured via a standard ELISA, as described in previous publications

Table I Demographics, thyroid function, and thyroid ultrasound findings at the first visit in seven patients with euthyroid Graves' disease

\begin{tabular}{|c|c|c|c|c|c|c|}
\hline \multirow{2}{*}{$\begin{array}{l}\text { Patient } \\
\text { number }\end{array}$} & \multirow[t]{2}{*}{ Age/sex } & \multirow[t]{2}{*}{ Ethnicity } & \multicolumn{2}{|c|}{ Thyroid function } & \multirow[t]{2}{*}{ Thyroid ultrasound } & \multirow[t]{2}{*}{ Histology ${ }^{a}$} \\
\hline & & & fT4 & TSH & & \\
\hline I & $63 / F$ & Caucasian & 12.6 & I.I & Normal & \\
\hline 2 & $53 / F$ & Malay & 16 & 1.91 & $\begin{array}{l}\text { One large nodule, one small } \\
\text { nodule, else normal }\end{array}$ & $\begin{array}{l}\text { Follicular cell adenoma, no lymphocytes } \\
\text { on FNA, or at thyroidectomy }\end{array}$ \\
\hline 3 & $50 / F$ & Asian & 9.9 & 0.84 & Not performed & Nil \\
\hline 4 & $60 / F$ & Asian & 14 & 0.69 & One small nodule, else normal & Nil \\
\hline 5 & $55 / F$ & Caucasian & 12.3 & 0.74 & Normal & Nil \\
\hline 6 & $49 / \mathrm{F}$ & Caucasian & 13 & 0.97 & $\begin{array}{l}\text { Several big nodules and } \\
\text { overall colloid features }\end{array}$ & $\begin{array}{l}\text { Colloid goiter, no lymphocytes at } \\
\text { thyroidectomy }\end{array}$ \\
\hline 7 & $30 / M$ & Lebanese & 13.8 & 0.87 & Enlarged, but normal texture & Nil \\
\hline
\end{tabular}

Notes: assessed from fine needle aspiration (FNA) biopsy (patients 2, 6) or thyroidectomy (patient 2).

Abbreviations: $\mathrm{fT}_{4}$, free $\mathrm{T} 4$; TSH, thyroid-stimulating hormone. 
Table 2 Thyroid antibodies, other autoantibodies, personal and family history of thyroid, and other autoimmune disorders in seven patients with euthyroid Graves' disease

\begin{tabular}{|c|c|c|c|c|c|c|c|c|}
\hline \multirow[t]{2}{*}{$\begin{array}{l}\text { Patient } \\
\text { number }\end{array}$} & \multicolumn{4}{|c|}{ Thyroid antibodies $^{\mathrm{a}}$} & \multicolumn{2}{|c|}{$\begin{array}{l}\text { Other } \\
\text { autoantibodies }\end{array}$} & \multirow{2}{*}{$\begin{array}{l}\text { Personal history } \\
\text { of thyroid or other } \\
\text { autoimmunity }\end{array}$} & \multirow[t]{2}{*}{$\begin{array}{l}\text { Known family history of thyroid } \\
\text { or other autoimmunity }\end{array}$} \\
\hline & TPO & $\mathrm{Tg}$ & TRAb & TSI & ANA & Other & & \\
\hline \multirow[t]{4}{*}{ I } & $<20$ & $<20$ & $<0.1$ & 8.45 & Neg & $\mathrm{Fp}$ & Nil & Hashimoto's thyroiditis \\
\hline & $<20$ & $<20$ & NT & 19.38 & & & & \\
\hline & $<20$ & $<20$ & NT & NT & & & & \\
\hline & $<20$ & $<20$ & NT & 6.89 & & & & \\
\hline \multirow[t]{3}{*}{2} & $<20$ & $<20$ & $<0.1$ & 17.64 & $\mathrm{Neg}$ & $\mathrm{Fp}$ & Nil & Nil known \\
\hline & $<20$ & $<20$ & NT & 20.79 & & & & \\
\hline & $<20$ & $<20$ & NT & 6.05 & & & & \\
\hline 3 & $<20$ & $<20$ & $<0.1$ & $|3.7|$ & Neg & NT & Nil & Rheumatoid arthritis \\
\hline \multirow[t]{4}{*}{4} & $<20$ & $<20$ & NT & NT & Neg & GPC & Vitiligo & Nil known \\
\hline & & & NT & 16.22 & & & & \\
\hline & & & NT & 25.07 & & & & \\
\hline & & & NT & 16.53 & & & & \\
\hline 5 & $<20$ & $<20$ & $<0.1$ & 13.16 & Neg & NT & Nil & Nil known \\
\hline 6 & $<20$ & $<20$ & $<0.1$ & 10.43 & NT & NT & Nil & Nil known \\
\hline 7 & $<20$ & $<20$ & NT & NT & NT & NT & Nil & Nil known \\
\hline
\end{tabular}

Notes: ${ }^{a}$ Thyroid antibodies were measured in a commercial ELISA; TSH-receptor antibodies were measured as TSH-r-binding antibody (TRAb) (ref range $<2$ IU/L) and as thyroid-stimulating immunoglobulin (TSI), (ref range $0 \%-19 \% \mathrm{~B} / \mathrm{B} 0$ ). Results are shown for the first and subsequent clinic visits.

Abbreviations: ANA, antinuclear antibody; Fp, flavoprotein (the 64-kDa protein); GPC, gastric parietal cell; NT, not tested; Tg, thyroglobulin (cut off titer 20); TPO, thyroid peroxidase (cut off titer 20).

from this laboratory., ${ }^{4,5,13,14}$ Purified rabbit skeletal muscle calsequestrin, which has 97\% homology with the human protein, was supplied by Dr Nicole Beard (ANU, Canberra, Australia) and recombinant human collagen XIII was provided by Drs Taina Pihlajaniemi and Tu Min (Oulu University, Finland). In preliminary studies, the assay was optimized in respect to antigen concentration and serum dilution as follows: $0.25 \mu \mathrm{g} / \mathrm{mL}$ for collagen XIII, and $0.5 \mu \mathrm{g} / \mathrm{mL}$ for $\mathrm{CASQ}_{1}$, and the optimal serum dilution was 1:25 for both antigens. The secondary antibody was a goat antihuman $\operatorname{IgG}$ at a dilution of 1 in 2000. A positive test was taken as an OD greater than the upper limit of normal for 30 healthy males aged $<30$ years; namely, 194 for $\mathrm{CASQ}_{1}$ and 174 for collagen XIII.

\section{Other tests}

Plasma-free thyroxin (fT4), and TSH and serum thyroglobulin (Tg) and thyroid peroxidise (TPO) antibodies were measured by Barratt and Smith Pathology (Sydney, Australia), using commercial kits according to the manufacturers' instructions. TSH-r antibodies were measured as (1) TRAb, using a commercial kit according to the manufacturer's instructions and (2) TSI, using fresh human thyroid cells as a source of human TSH-r and a commercial cAMP kit according to the manufacturer's instructions (all kits were from Barratt and Smith Pathology). Local Ethical Committee approval was received for the study and the informed consent of the participating subjects was obtained for the extra blood taken for research.

Table 3 Eye findings, smoking status, and treatment in seven patients with euthyroid Graves' disease

\begin{tabular}{|c|c|c|c|c|c|c|c|c|}
\hline \multirow{2}{*}{$\begin{array}{l}\text { Patient } \\
\text { number }\end{array}$} & \multirow{2}{*}{$\begin{array}{l}\text { Duration of } \\
\text { follow up } \\
\text { (years) }\end{array}$} & \multirow[t]{2}{*}{ Smokes } & \multicolumn{4}{|l|}{ Eye signs } & \multirow[t]{2}{*}{ Orbital CT findings } & \multirow[t]{2}{*}{ Treatment } \\
\hline & & & $\begin{array}{l}\text { NOSPECS } \\
\text { class }^{a}\end{array}$ & CAS & $\begin{array}{l}\text { Nunery } \\
\text { type }^{\text {b }}\end{array}$ & UER $^{\mathrm{d}}$ & & \\
\hline 1 & 8 & No & 4 & 4 & 2 & Yes & Enlarged EOM & Nil \\
\hline 2 & 10 & No & 4 & 4 & 2 & No & Enlarged EOM & $\begin{array}{l}\text { Prednisolone } \\
25 \mathrm{mg}\end{array}$ \\
\hline 3 & 6 & No & 3 & 5 & I & Yes & Normal EOM & Nil \\
\hline 4 & 8 & No & 2 & 3 & I & No & $\begin{array}{l}\text { Normal on two occasions } \\
\text { I year apart }\end{array}$ & $\begin{array}{l}\text { Prednisolone }(50 \mathrm{mg} / \text { day }) \\
+ \text { steroid eye drops }\end{array}$ \\
\hline 5 & 7 & No & 4 & I & 2 & No & EOM volumes increased & $\begin{array}{l}\text { Prednisolone } \\
7.5 \mathrm{mg}\end{array}$ \\
\hline 6 & 6 & No & 3 & 4 & I & No & Minimal EOM swelling & Nil \\
\hline 7 & 3 & No & 3 & 2 & 1 & Yes & $\begin{array}{l}\text { Normal EOM, dilated } \\
\text { ophthalmic vein }\end{array}$ & Nil \\
\hline
\end{tabular}

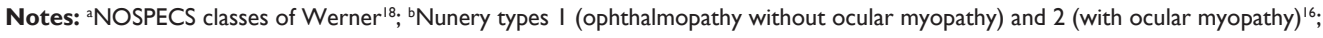

Abbreviations: CAS, clinical activity score of Mourits et al ${ }^{17}$; EOM, extraocular muscles; UER, upper eyelid retraction. 


\section{Statistical analysis}

Differences between the prevalence of smoking and positive serum calsequestrin and collagen XIII antibodies between patients with EGD and Graves' ophthalmopathy were assessed using Fisher's exact test (two-sided). A $P$ value of $<0.5$ was taken as significant in all assessments.

\section{Results}

\section{Thyroid antibodies}

TPO and Tg antibodies were measured on several occasions in all seven patients (Table 2). Although the methodology changed over the period of follow-up, the tests were carried out on many occasions and were always clearly negative. Although not tested as frequently, TSH-r antibodies, measured as TRAb, were negative in all five of the patients tested, while TSI tests were borderline positive in patients 1 and 2, on one occasion each, and strongly positive in patient 4,16 months after her first visit, but were otherwise negative (Table 2).

\section{Thyroid ultrasonography}

Thyroid ultrasound was carried out in six of the patients, of whom four had abnormalities; namely, a large suspicious nodule in patient 2 , which was shown at thyroidectomy to be a follicular adenoma, one small benign nodule in patient 4 , a multinodular goiter in patient 6 , which was confirmed as colloid nodules from fine needle aspiration (FNA) biopsy, and an enlarged thyroid with normal texture and no nodules in patient 7 . There was no evidence for thyroiditis in any of these patients at FNA (patients 4,6) or thyroidectomy (patient 2) (Table 1).

\section{Eye findings and orbital antibody levels}

The nature and severity of the eye signs at the first visit to the Thyroid Clinic, Nepean Hospital, are summarized in Table 3. In all patients, the eye disease had been present for some time and was considered moderately severe or severe, with CAS ranging from 1 to 5 and NOSPECS classes from 2 to 4 . The duration of the eye disease varied from 3-10 years. None of the patients were smokers. Orbital CT scans were carried out in all patients and showed definitely increased eye muscle volumes in three of them, all of whom had clinical eye muscle involvement (Nunery type 2, NOSPECS class 4). Three of the patients (patients 1,3,7) had UER. Three of the patients, all of whom had severe disease with eye muscle involvement (patients 2,5) or severe congestive changes (patient 4, see below), were being treated with steroids at the time of their first visit.
Serum orbital antibodies were measured in all seven patients, in five of whom two or more tests were carried out (Table 4). Initial CASQ ${ }_{1}$ tests were positive in only one patient (patient 2) but collagen XIII antibodies were detected in three of the patients (patients 3, 4, 7) at their first visit. On follow-up testing, $\mathrm{CASQ}_{1}$ antibodies were detected in patient 1 at the most recent visit only, patient 2 at the fourth and fifth visits - associated with worsening of her eye signs (see below) - and in patient 5 at the second visit only. Collagen XIII antibodies were positive in one or more serum samples from five of the seven patients (Table 4).

Patients 2, 4, and 7 were of special interest. Patient 2 initially had severe ophthalmopathy with eye muscle dysfunction (Nunery 2, CAS 3, NOSPECS class 4) but negative $\mathrm{CASQ}_{1}$ and collagen XIII antibody tests. The eye signs then improved over the next 2 years with steroid treatment (for 3 months) to Nunery 1, CAS 1, NOSPECS class 2, at which time both antibodies were positive, then worsened to CAS 2, NOSPECS class 3 (Nunery 1) as antibody tests became strongly positive (Table 4 ).

Patient 4 developed marked congestive ophthalmopathy in 2003, 3 years before she was first seen at the Thyroid Clinic, where she was studied in more detail. Throughout the study period her eyes had been variably itchy, gritty, watery, and swollen (CAS 3 or 4) with intermittent flareups requiring treatment with oral steroids, steroid eye drops, or both. At the time of her first clinic visit, she was being treated with prednisolone $50 \mathrm{mg}$ /day, which was reduced over the next 3 months, and was then stopped. She had never complained of double vision or reduced vision, and her eye muscle function had always been normal. A CT scan of her orbits carried out in 2005 and 2006 showed normal eye muscle volumes. She had no upper eyelid lag, or UER, or proptosis at any stage. $\mathrm{CASQ}_{1}$ antibody tests were always negative, while collagen XIII antibodies were positive in the early samples, then negative or borderline positive in later samples (Table 4).

Patient 7, the only male in the group, who was first seen in December 2010, had marked UER of the right eye, slight chemosis of the right eye, and $2 \mathrm{~mm}$ of proptosis when compared to the left eye, but no signs in the other (left) eye. He had no eye pain or diplopia (NOSPECS class 3, Nunery 1, UER). He slept with the right eye open. An orbital MRI showed normal extra ocular muscles (EOM) but a dilated ophthalmic vein and increased cerebrospinal fluid around the optic nerve. An MRI of the arteries and veins revealed no evidence for an AV malformation and there was no evidence of an orbital tumor. 
Table 4 Correlations between parameters of the ophthalmopathy and serum levels of thyroid and orbital antibodies in seven patients with euthyroid Graves' disease studied prospectively

\begin{tabular}{|c|c|c|c|c|c|c|c|}
\hline & & \multicolumn{4}{|c|}{ Ophthalmopathy } & \multicolumn{2}{|c|}{ Orbital antibodies $^{a}$} \\
\hline & & CAS & NOSPECS & Nunery & $\overline{\text { UER }}$ & CASQ $_{1}$ & CollXIII \\
\hline \multirow[t]{4}{*}{ I } & $9 / 05$ & 4 & 4 & 2 & No & 32 & 36 \\
\hline & $\mathrm{I} \mid / 05$ & 3 & 4 & 2 & No & 127 & 108 \\
\hline & $7 / 07$ & 3 & 2 & 2 & Yes & 92 & 97 \\
\hline & $3 / 09$ & 4 & I & I & No & 276 & 168 \\
\hline \multirow[t]{5}{*}{2} & $2 / 06$ & 3 & 4 & 2 & No & 186 & 83 \\
\hline & $5 / 06$ & 4 & 3 & I & No & 160 & 50 \\
\hline & $\mathrm{I} / 07$ & I & 2 & I & Yes & 74 & 275 \\
\hline & $1 / 08$ & I & 2 & I & Yes & 372 & 1043 \\
\hline & $7 / 08$ & 2 & 3 & I & No & 897 & 1228 \\
\hline 3 & $2 / 09$ & 4 & 3 & I & No & 40 & 467 \\
\hline \multirow[t]{6}{*}{4} & $4 / 06$ & 3 & 2 & I & No & 161 & 699 \\
\hline & $12 / 06$ & 3 & 2 & I & No & 105 & 203 \\
\hline & $9 / 07$ & 4 & 2 & I & No & 38 & 280 \\
\hline & $10 / 07$ & 3 & 2 & I & No & 55 & 106 \\
\hline & $8 / 08$ & 4 & 2 & 1 & No & 121 & 200 \\
\hline & $10 / 08$ & 4 & 2 & I & No & 153 & 207 \\
\hline \multirow[t]{3}{*}{5} & $6 / 07$ & I & 4 & 2 & No & 32 & 98 \\
\hline & $10 / 07$ & I & 4 & 2 & No & 235 & 424 \\
\hline & $9 / 10$ & I & 4 & 2 & No & 172 & 942 \\
\hline \multirow[t]{2}{*}{6} & $6 / 09$ & 4 & 4 & 2 & No & 0 & 163 \\
\hline & 9/09 & 2 & 3 & 2 & Yes & 150 & 44 \\
\hline 7 & $12 / 10$ & 2 & 3 & I & Yes & $N T^{f}$ & 573 \\
\hline
\end{tabular}

Notes: ${ }^{a}$ Orbital antibodies were measured in a standard ELISA (see methods); positive tests are indicated in bold. A positive test was taken as an OD $>$ the upper limit of normal for 30 healthy males aged <30; namely, 194 for CASQ, and I74 for collagen XIII; 'NOSPECS classes of Werner ${ }^{18}$; dnunery types I (ophthalmopathy without ocular myopathy) and 2 (with ocular myopathy). ${ }^{16}$

Abbreviations: CAS, clinical activity score of Mourits et $\mathrm{al}^{17}$; CASQ, skeletal muscle calsequestrin; CollXIII, collagen type XIII; UER, upper eyelid retraction; NT, not tested.

Except for patient 2 during the last 12 months of her follow-up where worsening congestive features were associated with high serum levels of both antibodies, and patient 4 , in whom levels of collagen XIII antibodies correlated generally with the severity of her congestive signs, there was no significant correlation between levels of either antibody and the clinical features (Table 3 ).

\section{Patients with Graves' ophthalmopathy}

For comparison, we studied a group of 13 patients with Graves' ophthalmopathy, twelve females and one male, seen at the Thyroid Clinic over the same period of time and matched for age, sex, ethnicity, and duration and severity of their eye disease with the patients with EGD. Details of their ophthalmopathy and serum levels of thyroid and orbital antibodies at the time of the first clinic visit and subsequently (orbital antibodies only) are summarized in Table 5. Their thyroid status was variable at the time of their first clinic visit depending on the stage of their disease and its treatment and thyroid antibodies were usually strongly positive. TSH-r antibodies were initially positive in all seven patients in whom this test was carried out. Three of the patients (patients 4, 6, 7) were being treated with prednisolone, alone, or with Imuran (two patients), at the time of their first clinic visit. Compared to the patients with EGD, the main differences were: (1) there were more smokers (eight out of 13 versus none out of seven, two-sided Fisher's exact test, $P<0.05$ ); (2) their thyroid glands were diffusely enlarged with increased vascularity, as expected, and a few had benign thyroid nodules on real-time ultrasonography; (3) calsequestrin antibodies were initially detected in five out of the $13(38 \%)$ patients in whom this test was performed, at the first clinic visit, while tests were always negative in the other six patients (results not shown) [compared to one out of seven (15\%) and four out of seven (67\%), respectively, patients with EGD (two-sided Fisher's exact test, $P=$ NS, $P=$ NS, respectively)] and; (4) collagen XIII antibodies were detected in five out of the $13(38 \%)$ patients in whom this test was performed, at the first clinic visit, and in another two patients at some time during their course (results not shown) (overall 75\% of patients) [compared to one out of $7(14 \%)$ and 5 out of 7 (71\%), respectively, EGD patients (two-sided Fisher's exact test, $P=\mathrm{NS}, P=\mathrm{NS}$, respectively)]. 
Table 5 Eye findings, smoking status, and treatment at the time of the first clinic visit in 13 patients with Graves' ophthalmopathy matched for age, sex, and ophthalmopathy severity, and activity with the patients with EGD

\begin{tabular}{|c|c|c|c|c|c|c|c|}
\hline $\begin{array}{l}\text { Patient } \\
\text { number }\end{array}$ & Age/sex & Ethnicity & $\begin{array}{l}\text { Duration of } \\
\text { follow-up (years) }\end{array}$ & $\begin{array}{l}\text { Personal history } \\
\text { of thyroid or other } \\
\text { autoimmunity }\end{array}$ & $\begin{array}{l}\text { Known family history } \\
\text { of thyroid or other } \\
\text { autoimmunity }\end{array}$ & Smokes (Y/N) & TRAb $^{\mathbf{a}}$ \\
\hline I & $38 / F$ & Caucasian & 6 & Nil & Scleroderma & Y & NT \\
\hline 2 & 58 & Caucasian & 4 & Nil & Premature grey hair & $Y$ & $>40$ \\
\hline 3 & 41 & Filipino & 5 & Nil & Nil & $\mathrm{N}$ & NT \\
\hline 4 & $47 / F$ & Caucasian & $1 \mathrm{I} / 2$ & Nil & Nil & $Y$ & $9.2(+)$ \\
\hline 5 & $63 / F$ & Caucasian & 6 & Nil & Nil & $\mathrm{N}$ & $>40$ \\
\hline 6 & $76 / F$ & Asian & 2 & Nil & Nil & $\mathrm{N}$ & 2.9 (pos) \\
\hline 7 & $5 \mathrm{I} / \mathrm{F}$ & Caucasian & 3 & Celiac disease & $\begin{array}{l}\text { Strong history of thyroid } \\
\text { autoimmunity in many } \\
\text { members of family }\end{array}$ & Y & $?$ \\
\hline 8 & $58 / F$ & Caucasian & 3 & Sjögren's disease & $\begin{array}{l}\text { Graves' disease, Graves' } \\
\text { ophthalmopathy }\end{array}$ & Y & NT \\
\hline 9 & $64 / F$ & Caucasian & 8 & Nil & Nil & $Y$ & 6.4 (pos) \\
\hline 10 & $50 / F$ & Caucasian & 2 & Nil & Nil & Y & $5.3(+)$ \\
\hline 11 & $30 / F$ & Caucasian & 3 & Nil & Nil & $\mathrm{N}$ & NT \\
\hline 12 & $64 / \mathrm{F}$ & Caucasian & 6 & Psoriasis & Graves' disease & $Y$ & 4.3 (pos) \\
\hline 13 & $44 / M$ & Caucasian & 2 & Nil & Nil & $\mathrm{N}$ & $>40$ \\
\hline
\end{tabular}

\section{Discussion}

That the ophthalmopathy of Graves' disease can occur in the apparent absence of hyperthyroidism or hypothyroidism is well known, but it is not clear whether the two disorders have the same pathogenesis. Here, we report seven patients with "EGD" who were studied over a 10-year period and who have not developed Hashimoto's thyroiditis or Graves' disease as determined from thyroid function tests, thyroid antibody testing and, where available, histological examination of their thyroid tissue at thyroidectomy or FNA biopsy. Some of the patients had a personal or family history of other autoimmune disorders or autoantibodies, suggesting that "autoimmune ophthalmopathy" can be considered one component of a limited, multisystem autoimmune disorder, as previously postulated. ${ }^{19,20}$

Serum calsequestrin and collagen XIII antibodies were measured in these patients and real-time thyroid ultrasonographic findings are reported. Included in these seven patients was a patient with severe congestive ophthalmopathy, but who had no evidence for eye muscle damage, in whom collagen XIII antibodies were initially positive and then became negative and in whom antibodies targeting calsequestrin were always negative. We believe that this case study supports the role of autoimmunity against collagen XIII in the pathogenesis of a putative congestive ophthalmopathy subtype of thyroid eye disease.

In an earlier study, ${ }^{21}$ we found that all patients with EGD who were followed for up to 3 years developed clinical or immunological evidence for either Hashimoto's thyroiditis or Graves' disease. Then, in a study where we additionally tested for cytotoxicity against thyroid and eye muscle cells in patients with EGD, over half of a group of patients with EGD showed evidence of thyroid autoimmunity. ${ }^{22}$ However, most of these latter patients would now have been classified as having Hashimoto's thyroiditis with upper eyelid disease, rather than as having "EGD."

For comparison, a group of 13 age-, sex-, and ethnicitymatched patients with typical Graves' ophthalmopathy who attended the thyroid clinic over the same period of time, and who had similar eye disease in respect of activity and severity were studied. Overall, there were no significant differences between the two groups in respect to the prevalence 


\begin{tabular}{|c|c|c|c|c|c|c|c|c|c|}
\hline \multicolumn{4}{|l|}{ Eye signs } & \multirow{2}{*}{$\begin{array}{l}\text { Orbital imaging } \\
\text { findings }\end{array}$} & \multirow{2}{*}{$\begin{array}{l}\text { Thyroid } \\
\text { antibodies }^{b} \\
\text { TPO/Tg }\end{array}$} & \multicolumn{2}{|l|}{ Treatment } & \multicolumn{2}{|c|}{ Orbital antibodies ${ }^{c}$} \\
\hline $\begin{array}{l}\text { NOSPECS } \\
\text { Class }\end{array}$ & CAS $^{e}$ & $\begin{array}{l}\text { Nunery } \\
\text { type }^{f}\end{array}$ & UER $^{g}$ & & & Eyes & Thyroid & CASQ $_{1}$ & CollXIII \\
\hline 2 & 2 & 1 & Yes & Not performed & Neg/neg & Nil & LT4 & 350 & 126 \\
\hline 4 & 5 & 2 & Yes & Not performed & 100/neg & Nil & Carb & 48 & 130 \\
\hline 2 & 2 & I & Yes & Not performed & Neg/neg & Nil & LT4 & 194 & 109 \\
\hline 4 & 4 & 2 & Yes & $\begin{array}{l}\text { Increased EOM } \\
\text { volumes }\end{array}$ & $1600 / 100$ & $\begin{array}{l}\text { Prednisolone } \\
10 \mathrm{mg}\end{array}$ & LT4 & 147 & 233 \\
\hline 4 & 4 & 2 & Yes & Normal & $400 / 400$ & Nil & Nil & 261 & 204 \\
\hline 5 & 3 & 2 & Yes & $\begin{array}{l}\text { Increased EOM } \\
\text { volumes }\end{array}$ & Neg/neg & $\begin{array}{l}\text { Prednisolone } \\
10 \mathrm{mg} / \text { day } / \mathrm{lmuran}\end{array}$ & LT4 & NT & NT \\
\hline 4 & 4 & 2 & Yes & $\begin{array}{l}\text { Increased EOM } \\
\text { volumes }\end{array}$ & Neg/neg & $\begin{array}{l}\text { Prednisolone } \\
5 \mathrm{mg} / \text { day/lmuran }\end{array}$ & LT4 & 39 & $|89|$ \\
\hline 4 & 3 & 2 & No & Not performed & $400 /$ neg & Nil & LT4 & 15 & 15 \\
\hline 4 & 5 & 2 & Yes & $\begin{array}{l}\text { Increased EOM } \\
\text { volumes }\end{array}$ & $>1600 />1600$ & $\begin{array}{l}\text { Nil at first visit, } \\
\text { later selenium } \\
100 \mu \mathrm{g} \text { bds }\end{array}$ & LT4 & 90 & 106 \\
\hline 3 & 2 & 1 & No & Not performed & $>25600,1600$ & Nil & LT4 & 496 & 241 \\
\hline 2 & 2 & I & No & Not performed & & Nil & LT4 & 344 & 175 \\
\hline 4 & 5 & 2 & Yes & Not performed & $>1000,91$ & Nil & LT5 & II & 110 \\
\hline 4 & 4 & 2 & Yes & Not performed & Neg/neg & Nil & Carb & 20 & 0 \\
\hline
\end{tabular}

Notes: bthyroid antibodies were measured in a commercial ELISA; CAS, clinical activity score of Mourits et al ${ }^{17}$; ${ }^{\text {' }}$ orbital antibodies were measured in a standard ELISA (see methods); positive tests are indicated in bold. A positive test was taken as an OD $>$ the upper limit of normal for 30 healthy males aged $<30$; namely, 194 for CASQ, and 174 for collagen XIII; ${ }^{\circ}$ NOSPECS classes of Werner ${ }^{18}$; ; ' nunery types I (ophthalmopathy without ocular myopathy) and 2 (with ocular myopathy) ${ }^{16}$.

Abbreviations: CAS, clinical activity score of Mourits et al' ${ }^{17} \mathrm{CASQ}_{1}$, skeletal muscle calsequestrin; CollXIII, collagen type XIII; EGD, enthyroid graves' disease; NT, net tested; Tg, thyroglobulin (cut off titer 20); TRAB, TSH-r-binding antibody; TRAb, TSHr antibodies; TPO, thyroid peroxidase (cut off titer 20); UER, upper eyelid retraction.

of calsequestrin and collagen XII antibodies, but there were significantly more smokers among the Graves' ophthalmopathy patients, the significance of which is unclear. This suggests that the ophthalmopathy is the same whether it is associated with thyroid autoimmunity or not, and that it is one feature of an autoimmune cluster that includes thyroid autoimmunity and inflammation of the bones, skin, and lacrimal glands.

Collagen XIII is a fibroblast cell membrane protein and serum antibodies against collagen XIII have been linked to recent onset, congestive ophthalmopathy in patients with Graves' ophthalmopathy. ${ }^{14,15}$ Five of our patients had detectable collagen XIII antibodies, including patient 4 , in whom serum levels correlated generally with the clinical severity of her eye signs and symptoms. Since collagen XIII is expressed in the orbital fibroblast cell membranes ${ }^{12}$ its targeting by collagen XIII antibodies might lead to fibroblast stimulation, fibrosis, and glycosaminoglycans overproduction - well recognized features of Graves' ophthalmopathy. ${ }^{23,24}$

The TSH-r is expressed in the orbital preadipocytes and fibroblasts and many researchers propose that its targeting there leads to the development of ophthalmopathy. ${ }^{2,7,9}$
However, in patient 4 with severe isolated congestive ophthalmopathy, TSH-r antibodies were always negative, except for one strongly positive test, as TSI, on one occasion, and the overall prevalence of these antibodies was lower than in patients with Graves' ophthalmopathy. It is therefore tempting to conclude that these antibodies play no major role in the pathogenesis of this "autoimmune ophthalmopathy." However, TSH-r antibodies might have been present before the onset of ophthalmopathy in patients without associated thyroid disease, but not tested for. In order to elucidate the significance of TSH-r antibodies, a long-term study of patients with recent onset ophthalmopathy with and without thyroid autoimmunity in which the TSH-r-binding-blocking antibodies that have been implicated in the pathogenesis of Graves' ophthalmopathy, ${ }^{25}$ other TSH-r antibodies, as well as calsequestrin, Fp, and collagen XIII antibodies are measured, needs to be carried out.

The major calcium-binding protein, $\mathrm{CASQ}_{1}$, seems to be an important target of the autoimmune reactions of the eye muscle component of the ophthalmopathy associated with Graves' hyperthyroidism ("Graves ophthalmopathy") ${ }^{26,27}$ and 
of the upper eyelid muscle reaction of Hashimoto's thyroiditis. ${ }^{5}$ $\mathrm{CASQ}_{1}$ is expressed 4.7 times more in eye muscle than in other skeletal muscle, ${ }^{28}$ which could partly explain the localization of skeletal muscle inflammation in the orbit and upper eyelids in these patients.

Finally, although out of the scope of the present study, the role of cytokines and other chemokines in the pathogenesis of ophthalmopathy is also likely to be important..$^{29,30}$ It is interesting to speculate that the profile of these mediators may differ in patients with "EGD" and those with typical Graves' ophthalmopathy, that is, where there is associated thyroid autoimmunity. The role of cytokines and T-cell autoimmunity can be studied in an animal model for "autoimmune ophthalmopathy," which we are currently developing.

In conclusion, earlier studies suggesting that patients with EGD eventually develop thyroid dysfunction have not been confirmed here, although the possibility that patients with "EGD" had thyroid autoimmunity in the past, or that they will develop it in the future, cannot be excluded. Overall, it is likely that the ophthalmopathy associated with Graves' hyperthyroidism ("Graves' ophthalmopathy") is the same disease as that observed in patients, such as those reported here, in whom thyroid dysfunction and thyroid autoimmunity are not present initially, nor where such dysfunction and autoimmunity do not develop during the period of follow-up that we have called "EGD". In both cases, there is an association with other autoimmune disorders or markers. As the role of autoimmunity against the TSH-r in ophthalmopathy has not been proven, and because the significance of orbital antibodies is unclear, additional pathogenetic mechanisms for this autoimmune eye disorder need to be considered.

\section{Acknowledgments}

We thank Dr Harry Grunstein for providing clinical information about one of the patients, Dr Gary Ma for performing the TSH-r antibody tests, Drs Tania Pihlajaniemi and Hongmin $\mathrm{Tu}$ (Oulu, Finland) for supplying the collagen XIII protein, and Dr Nicole Beard (The John Curtin School of Medical Research, ACT, Australia) for supplying purified rabbit skeletal muscle calsequestrin.

\section{Disclosure}

The authors report no competing financial interests in this work.

\section{References}

1. Wiersinga WM, Bartalena L. Epidemiology and prevention of Graves' ophthalmopathy. Thyroid. 2002;12:855-860.
2. Burch HB, Wartofsky L. Graves' ophthalmopathy: Current concepts regarding pathogenesis and management. Endocr Rev. 1993;14: 747-793.

3. Bartley GB, Fatourechi V, Kadrmas EF, et al. Clinical features of Graves' ophthalmopathy in an incidence cohort. Am J Ophthalmol. 1996;121:284-290.

4. Gopinath B, Tani J, Bao N, Wall JR. Eye muscle and collagen XIII antibodies and eye signs in patients with transient and chronic thyroiditis. Thyroid. 2007;17:1-7.

5. Tjiang H, Lahooti H, McCorquodale T, Parmar KR, Wall JR. Eye and eyelid abnormalities are common in patients with Hashimoto's thyroiditis. Thyroid. 2010;20:287-290.

6. Eckstein AK, Plicht M, Lax H, et al. Thyrotropin receptor autoantibodies are independent risk factors for Graves' ophthalmopathy and help to predict severity and outcome of the disease. J Clin Endocrinol Metab. 2006;91:3464-3470.

7. Paschke R, Vassart G, Ludgate M. Current evidence for and against the TSH receptor being the common antigen in Graves' disease and thyroid associated ophthalmopathy. Clin Endocrinol (Oxf). 1995;42:565-569.

8. Weetman AP. Graves' disease. N Engl J Med. 2000;343:1236-1248.

9. Bahn RS. Clinical review 157: Pathophysiology of Graves' ophthalmopathy: The cycle of disease. J Clin Endocrinol Metab. 2003; 88:1939-1946.

10. Wall JR. The TSH-receptor and thyroid-associated ophthalmopathy: A convenient hypothesis with too many exceptions to be true. Int $J$ Endocrinol Metab. 2007;2:49-51.

11. Beard NA, Laver DR, Dulhunty AF. Calsequestrin and the calcium release channel of skeletal and cardiac muscle. Biophys Mol Biol. 2004;85:33-69.

12. Hagg P, Rehn M, Huhtala P, Vaisanen T, Tamminen M, Pihlajaniemi T. Type XIII collagen is identified as a plasma membrane protein. $J$ Biol Chem. 1998;273:15590-15597.

13. Gopinath B, Musselman R, Beard N, Tani J, Adams C, Wall JR. Antibodies targeting the calcium binding skeletal muscle protein calsequestrin are sensitive and specific markers of ocular myopathy in patients with Graves' disease. Clin Exp Immunol. 2006;145: 56-62.

14. Gopinath B, Musselman R, Adams C, Tani J, Beard N, Wall JR. Study of serum antibodies against three eye muscle antigens and the connective tissue antigen collagen XIII in patients with Graves' disease with and without ophthalmopathy: Correlation with clinical features. Thyroid. 2006;16:967-974.

15. De Bellis A, Sansone D, Coronella C, et al. Serum antibodies to collagen XIII: A further good marker of active Graves' ophthalmopathy. Clin Endocrinol (Oxf). 2005;62:24-29.

16. Nunery WR, Martin RT, Heinz GW, Gavin TJ. The association of cigarette smoking with clinical subtypes of ophthalmic Graves' disease. Ophthal Plast Reconstr Surg. 1993;9:77-82.

17. Mourits MP, Koornneef L, Wiersinga WM, Prummel MF, Berghout A, van der Gaag R. Clinical criteria for the assessment of disease activity in Graves' ophthalmopathy: A novel approach. Br J Ophthalmol. 1989;73: 639-644.

18. Werner SC. Classification of the eye changes of Graves' disease. Am J Ophthalmol. 1969;68:646-648.

19. Wall JR, Kiljanski J, Nebes V, Stachura I, Kennerdell JS. Should Graves' disease be considered a collagen disorder of the thyroid, skeletal muscle and connective tissue? Hor Metab Res. 1995;27:528-532.

20. Wall JR. Extra thyroidal manifestations of Graves' disease. J Clin Endocrinol Metab. 1996;80:3427-3429.

21. Salvi M, Zhang ZG, Haegert D, et al. Patients with endocrine ophthalmopathy not associated with overt thyroid disease have multiple thyroid immunological abnormalities. J Clin Endocrinol Metab. 1990;70:89-94.

22. Medeiros-Neto G, Zhang ZG, Lima N, et al. Immunologically mediated cytotoxicity against human eye muscle and thyroid cells in euthyroid and thyrotoxic Graves' ophthalmopathy. Autoimmunity. 1991;9:293-300. 
23. Hansen C, Fraiture B, Rouhi R, Otto E, Förster G, Kahaly G. HPLC glycosaminoglycan analysis in patients with Graves' disease. Clin Sci (Lond). 1997;92:511-517.

24. Kahaly G, Stover C, Otto E, Beyer J, Schuler M. Glycosaminoglycans in thyroid-associated ophthalmopathy. Autoimmunity. 1992;13:81-88.

25. Kim WB, Chung HK, Park YJ, et al. The prevalence and clinical significance of blocking thyrotropin receptor antibodies in untreated hyperthyroid Graves' disease. Thyroid. 2000;10:579-586.

26. Tani J, Wall JR. Analysis: Can the development of thyroid-associated ophthalmopathy be explained by autoimmunity against eye muscle antigens? Canad Med Assoc. 2006;17:239-241.

27. Tani J, Gopinath B, Nuygen B, Wall JR. Immunological mechanisms for the eye muscle and orbital connective tissue reactions of thyroid-associated ophthalmopathy. Expert Rev Clin Immunol. 2007;3:299-311.
28. Porter JD, Khanna S, Kaminski HJ, et al. Extraocular muscle is defined by a fundamentally distinct gene expression profile. Proc Natl Acad Sci U S A. 2001;98:12062-12067.

29. Huang D, Xu N, Song Y, Wang P, Yang H. Inflammatory cytokine profiles in the tears of thyroid-associated ophthalmopathy. Graefes Arch Clin Exp Ophthalmol. 2012;250(4):619-625.

30. Khalilzadeh O, Anvari M, Esteghamati A, et al. Genetic susceptibility to Graves' ophthalmopathy: The role of polymorphisms in antiinflammatory cytokine genes. Ophthalmic Genet. 2010;31:215-220.
Clinical Ophthalmology

\section{Publish your work in this journal}

Clinical Ophthalmology is an international, peer-reviewed journal covering all subspecialties within ophthalmology. Key topics include: Optometry; Visual science; Pharmacology and drug therapy in eye diseases; Basic Sciences; Primary and Secondary eye care; Patien Safety and Quality of Care Improvements. This journal is indexed on

Submit your manuscript here: http://www.dovepress.com/clinical-ophthalmology-journal

\section{Dovepress}

PubMed Central and CAS, and is the official journal of The Society of Clinical Ophthalmology (SCO). The manuscript management system is completely online and includes a very quick and fair peer-review system, which is all easy to use. Visit http://www.dovepress.com/ testimonials.php to read real quotes from published authors. 